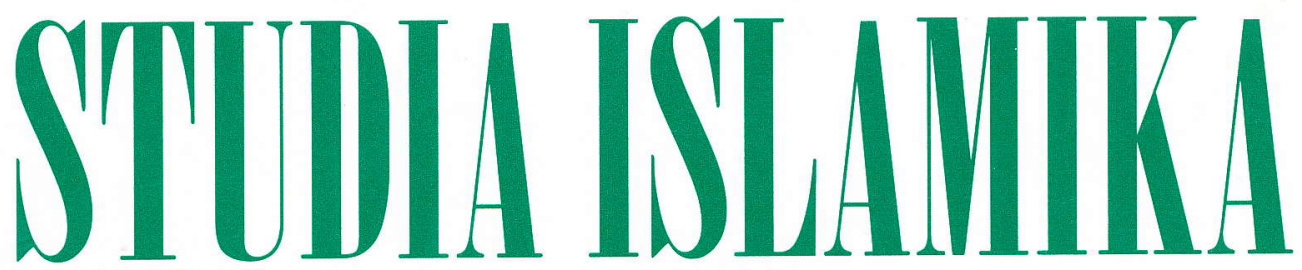

INDONESIAN JOURNAL FOR ISLAMIC STUDIES

Volume 11, Number 1, 2004

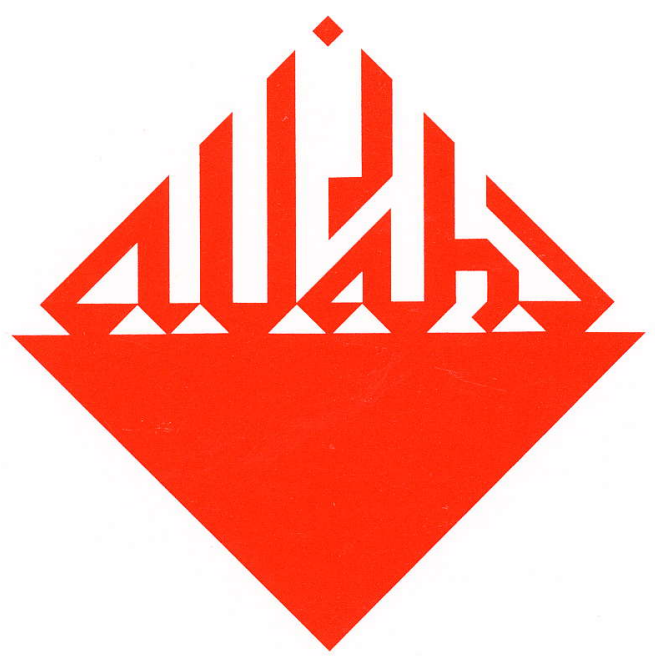

PONDOKS, MADRASAHS AND THE PRODUCTION OF 'ULAMĀ' IN MALAYSIA

William R. Roff

THE FRAGMENTATION OF RELIGIOUS AUTHORITY:

ISLAMIC PRINT MEDIA IN EARLY $20^{\text {TH }}$ CENTURY INDONESIA

\title{
Jajat Burhanudin
}

ON THE GENESIS OF INTELLECTUAL CROSSROADS: EARLY FRAGMENTATION IN THE FORMATION OF MODERN INDONESIAN INTELLIGENTSIA 


\section{STIIILA ISLLIIILI \\ Indonesian Journal for Islamic Studies \\ Vol. 11, no. 1,2004}

EDITORIAL BOARD:

M. Quraish Shihab (UIN Jakarta)

Taufik Abdullah (LIPI Jakarta)

Nur A. Fadhil Lubis (IAIN Sumatra Utara)

M.C. Ricklefs (Melbourne University)

Martin van Bruinessen (Utrecht University)

John R. Bowen (Washington University, St. Louis)

M. Atho Mudzhar (IAIN Yogyakarta)

M. Kamal Hasan (International Islamic University, Kuala Lumpur)

EDITOR-IN-CHIEF

Azyumardi Azra

EDITORS

Saiful Mujani

Jamhari

Jajat Burhanuddin

Fu'ad Jabali

Oman Fathurahman

ASSISTANT TO THE EDITORS

Heni Nuroni

ENGLISH LANGUAGE ADVISOR

Lucy Rhydiven-Marett

ARABIC LANGUAGE ADVISOR

Nursamad

COVER DESIGNER

S. Prinka

STUDIA ISLAMIKA (ISSN 0215-0492) is a journal published by the Center for the Study of Islam and Society (PPIM) UIN Syarif Hidayatullah, Jakarta (STT DEPPEN No. 129/SK/DITJEN/PPG/STT/1976) and sponsored by the Australia-Indonesia Institute (AII). It specializes in Indonesian Islamic studies in particular, and South-east Asian Islamic Studies in general, and is intended to communicate original researches and current issues on the subject. This journal warmly welcomes contributions from scholars of related disciplines.

All articles published do not necessarily represent the views of the journal, or other institutions to which it is affiliated. They are solely the views of the authors. The articles contained in this journal have been refereed by the Board of Editors.

STUDIA ISLAMIKA has been accredited by The Ministry of National Education, Republic of Indonesia as an academic journal (SK Dirjen Dikti No. 23a/DIKTI/2004). 


\section{William R. Roff}

\section{Pondoks, Madrasahs and the Production of 'Ulamā' in Malaysia'}

Abstrak: Artikel ini membahas perkembangan institusi Islam terdepan di dunia Melayu, pondok dan madrasah, yang terjadi menyusul perubahan sistem politik dari kerajaan hingga ke negara Malaysia modern maupun sistem sosial-budaya yang menyertainya. Di sini, fokus kajian diarahkan terutama pada perubahan salah satu peran penting yang telah lama diemban, sebagai pusat produksi ulama.

Pondok, di Indonesia dikenal dengan pesantren, merupakan pusat pembelajaran Islam, dan sekaligus berperan mencetak mereka yang ahli di bidang agama Islam, ulama. Sistem pendidikan pondok ini sedemikian mapan pada abad ke-19. Hal ini antara lain juga didorong oleh meningkatnya hubungan dunia Melayu dengan Timur Tengah, khususnya Mekkah dan Madinah. Para haji dan ulama jebolan Mekkah-bersama kitab jawi yang mereka perkenalkan-telah memperbesar otoritas keagamaan pondok. Akibatnya, bukan hanya masyarakat Muslim yang percaya untuk mengirim anak-anak mereka belajar Islam di pondok, tapi juga pihak kerajaan dan pemerintah kolonial. Pihak terakhir ini membutuhkan alumni pondok untuk mengisi sejumlah jabatan dalam institusi keagamaan yang sengaja dirancang dalam rangka usaha restrukturisasi institusi hukum Islam. Pada periode itu, Peradilan Syari'ah, Baitul Mal, dan Majlis Agama didirikan. Alumni pondok pun menduduki jabatan qadi, imam, mufti, dan sejumlah pos lain.

Pada azval abad ke-20, seiring dengan reformasi Islam dan modernisasi sosial-budaya yang didorong pihak kolonial, sejumlah perubahan mendasar berlangsung di pondok. Di sini, pondok mengalami transformasi menjadi madrasah. Berbeda dengan pondok yang khusus dirancang untuk 
pendidikan keagamaan, madrasah menjadikan sejumlah mata pelajaran umum ke dalam kurikulum. Berbeda pula dengan pondok yang sematamata mengkaji kitab Jazvi, madrasah mulai bergerak dalam penerbitan teks-teks keagamaan baru. Penting dicatat, proses transformasi ini juga didorong tumbuhnya orientasi baru di Timur Tengah, di mana komunitas Jawi-yang sebelumnya menjadi agen terdepan dalam proses transmisi Islam ke dunia Melayı-mulai bersentuhan dengan pembaharuan Islam di Kairo, Mesir.

Sekadar contoh, kita mencatat di sini Madrasah al-Iqbal al-Islamiyah. Berdiri pada 1908, Madrasah ini menjadi lembaga pendidikan Islam modern pertama. Tokoh gerakan pembaharuan Islam di Melayu, khususnya Sayyid Shaikh al-Hadi dan Thaher Djalaluddin berada di belakang pendirikan madrasah tersebut. Di samping menerbitkan al-Imam (19061908)_jurnal pembaharuan Islam di dunia Melayu-mereka juga menjadikan al-Igbal al-Islamiyah sebagai satu agenda penting untuk diseminasi gagasan pembaharuan Islam. Munculnya Madrasah ini kemudian diikuti oleh pendirian sejumlah madrasah di negara-negara lain di dunia Melayu, seperti Madrasah al-Ihsaniyah di Teluk Anson, Perak, Madrasah Jam'iyyah al-Khairiyyah di Muar, Johor, dan Madrasah alKhairiyyah di Kota Bharu, Kelantan. Seperti halnya al-Igbal al-Islamiyah, madrasah-madrasah ini mulai menerapkan sistem dan metode pendidikan modern.

Berkaitan dengan perannya sebagai pencetak ulama, madrasah tidak berbeda dari pondok. Modernisasi sosial dan institusi keagamaan, termasuk lembaga hukum, juga mensyaratkan Iulusan pendidikan Islam modern seperti madrasah. Bahkan, seiring dengan gerakan untuk kemerdekaan, banyak lulusan madrasah yang kemudian terlibat dalam gerakan politik. Partai-partai politik terkemuka di Malaysia pun, seperti UMNO (United Malay National Organization) dan partai kiri nasional Melayu berhaluan radikal (Malay National Party $=$ MNP), membutuhkan dukungan ulama. Meski demikian, perlu ditekankan bahwa institusi madrasah justru mengalami kemunduran. Hal ini selain karena faktor internal kelembagaan, juga karena kebijakan pemerintah Malaysia yang mendirikan Sekolah Agama Kerajaan. Akibatnya, madrasah-bahkan pondok yang saat itu masih eksis-menjadi sekolah terbelakang, yang tidak bisa memenuhi standar akademik yang ditetapkan pemerintah. Dalam kondisi demikian, harapan masyarakat terhadap peran madrasah juga memudar, begitu juga pemerintah. Akhirnya, meski perlahan, madrasah secara pasti terus mengalami kemunduran. Lulusan madrasah tidak lagi bisa memenuhi harapan masyarakat terhadap sosok ulama yang terus mengalami perubahan. 
William R. Roff

Pondoks, Madrasahs and the Production

of 'Ulamā' in Malaysia'

\section{خلاصة}

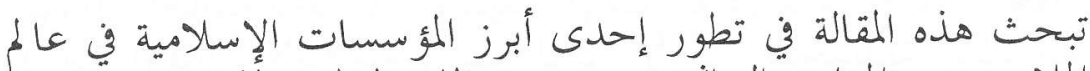

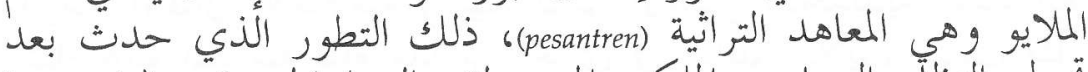

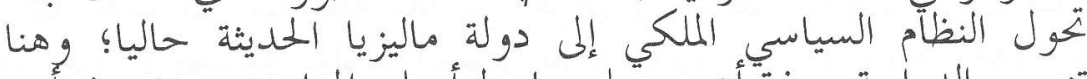

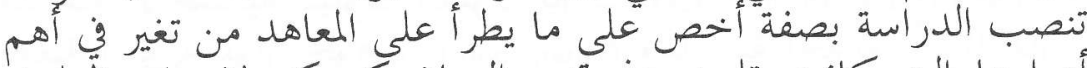

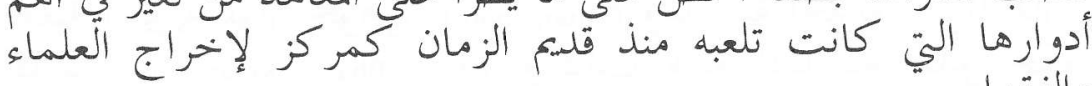
و الفقهاء.

و في إندونيسيا كانت المعاهد التراثية مركزا لتعليم الإسلام وتقوم

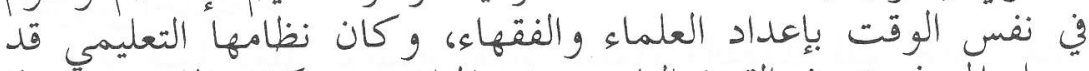

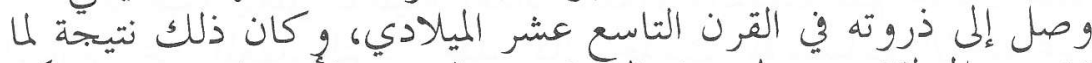

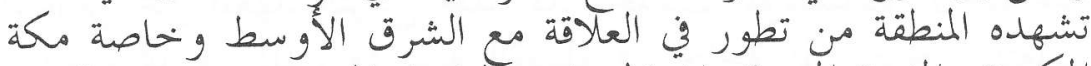

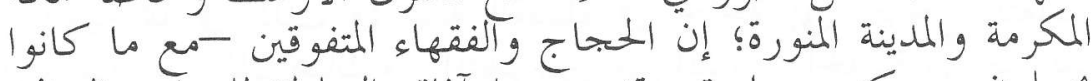

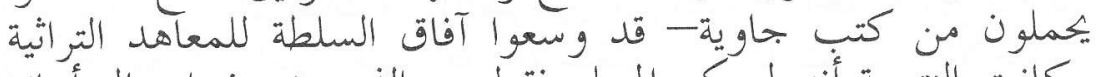

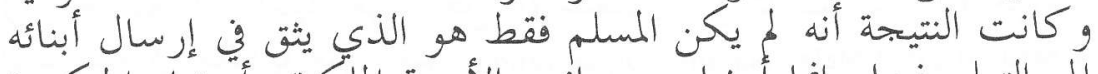

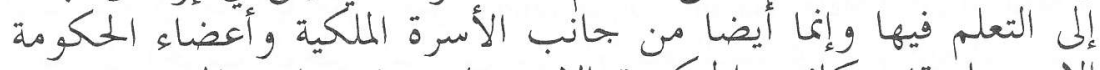

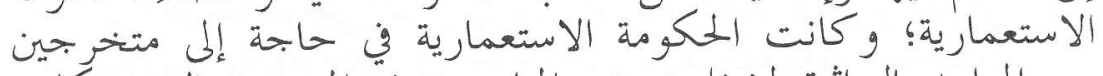

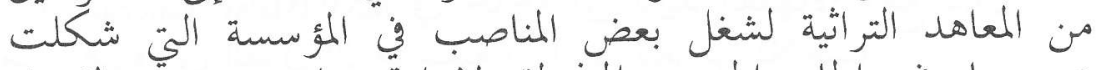

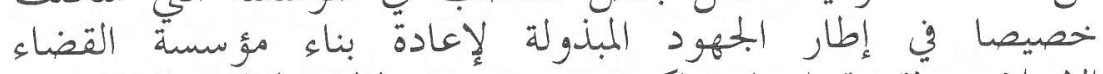

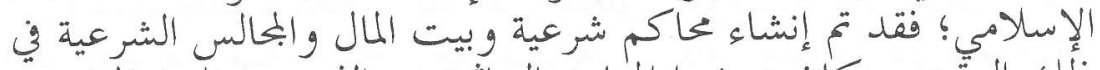

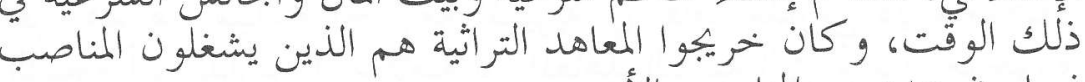
فيها وفي عدد من المناصب الأبر الأخرى.

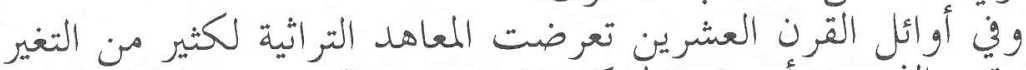

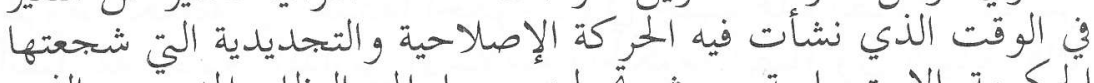

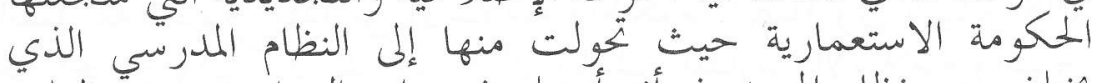

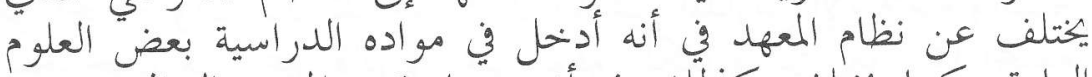

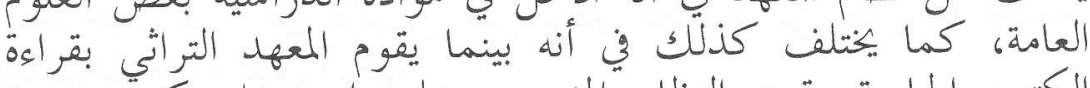

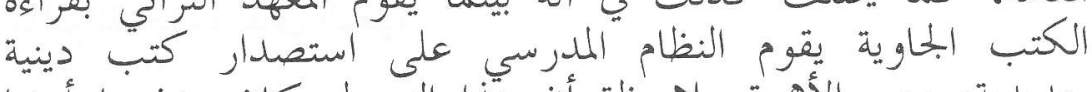

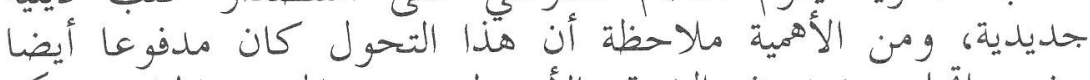

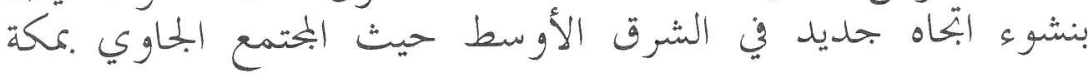




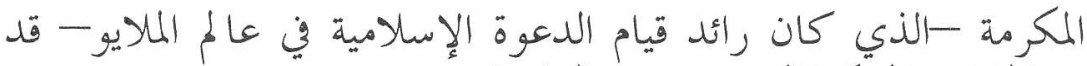

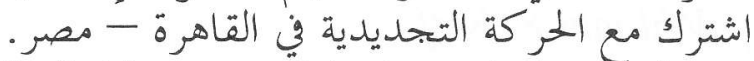

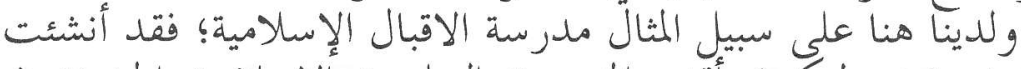

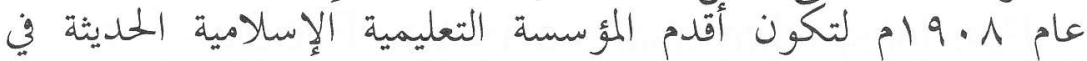

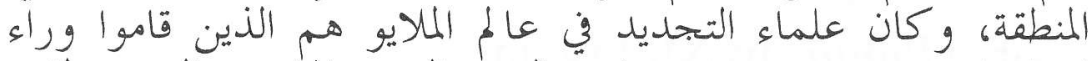

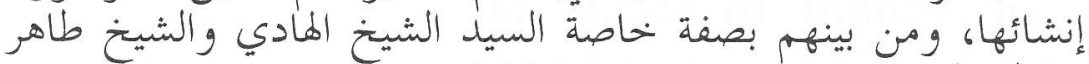

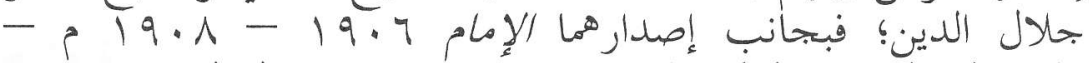

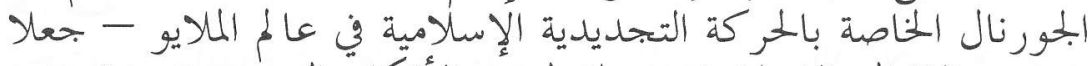

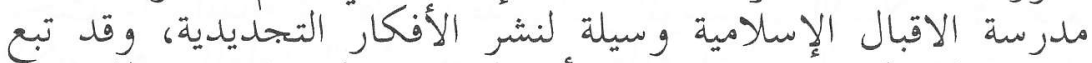

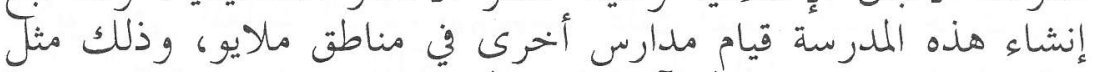

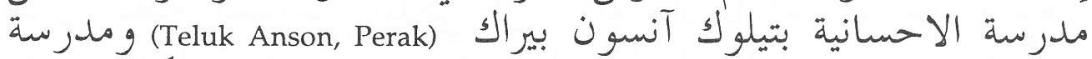

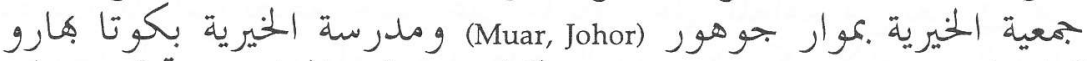

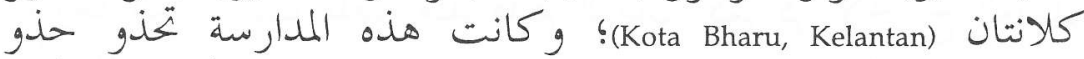
مدرسة الإقبال الإسالامية في تطبيق النظام التعليمي الحلديث ورنات وطرق التدريس الحلديثة. الإقبال

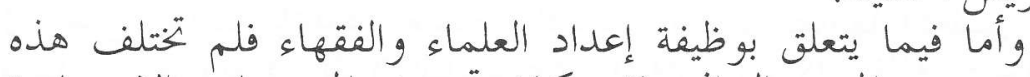

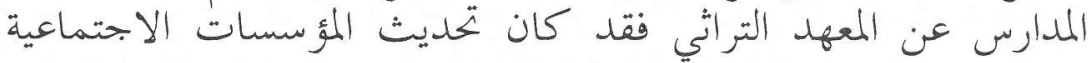

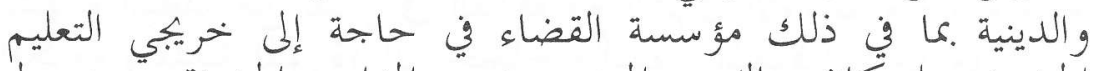

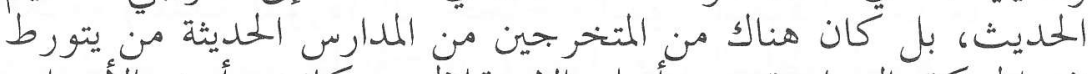

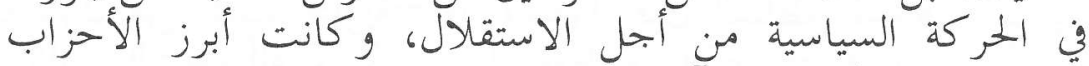

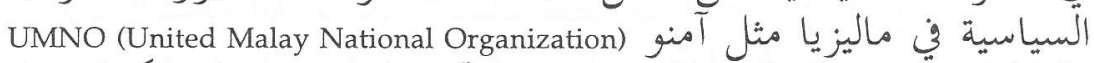

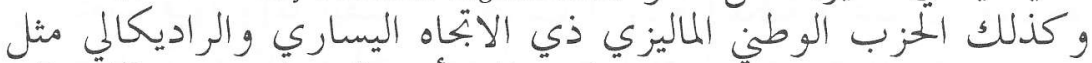
من MNP (Malay National Party)

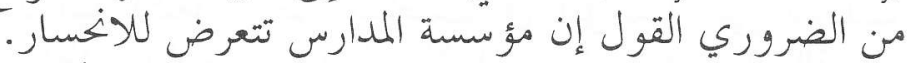

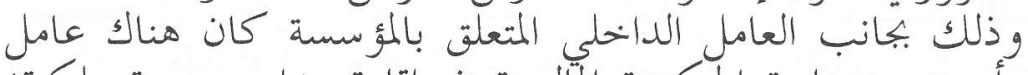

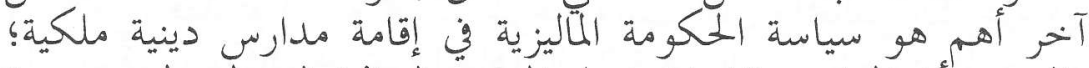

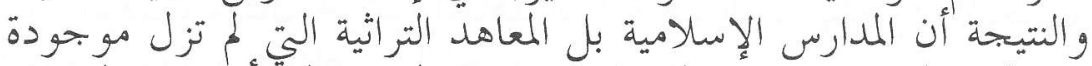

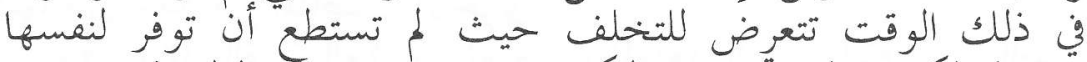

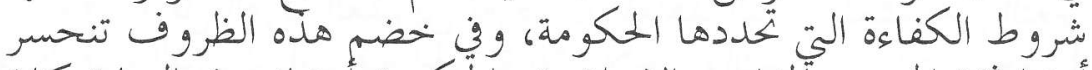

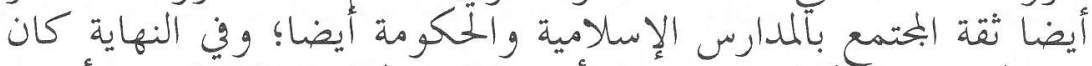

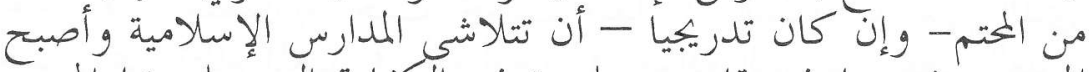

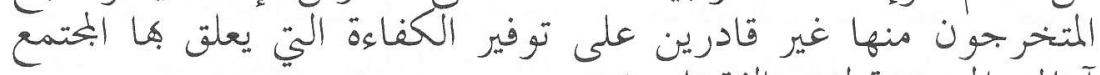

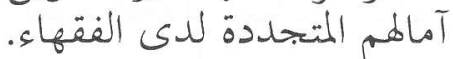


$\square$ his essay traces the development of pondoks, or peoples' Islamic schools (sekolah agama rakyat), in nineteenth and 1 twentieth century Malay peasant society, their evolution into institutions styled madrasahs, and the role both played in the production of 'ulama'. Their equivalents in Indonesia, generally known as pesantren, have been the subject of substantial research and several notable published studies. ${ }^{2}$ Though this has been much less true for Malaysia, the scattered material that does exist perhaps warrants the following attempt to piece it together.

The nine sultanate states of early nineteenth century peninsular Malaya were populated almost entirely by Malay peasant farmers engaged in wet-rice cultivation and, on the East coast in particular, fishing. Strategically situated between the Indian Ocean and the South China Sea, the peninsula had long been visited by numerous foreigners - Chinese, Arabs, South Asians and Europeans. Though the gold deposits that were an early lure had long been exhausted, alluvial tin had by the nineteenth century attracted growing numbers of Chinese miners, who worked the lodes under the auspices of local Malay rulers and district chiefs. It was this influx and resulting political unrest between warring factions of both Chinese and Malays, that in the 1870s became the rationale for direct British involvement in the Malay states, spurred on by merchants in the commercial entrepots of Penang and Singapore, which dated from a little earlier.

British colonial dominion over the peninsula during the course of the next several decades transformed for all its inhabitants the conditions under which their lives were led -through vast inmigrations of Chinese, South Asian and (to a much smaller extent) Javanese and Sumatran immigrants to service the extractive mining and agribusiness economy and the administrative and communications infrastructures associated with it. During the half century that followed - up to World War II- the Malay peasantry, and much of the ruling class, islanded in a sea of change in which they were not required, and indeed seldom permitted, to participate directly, saw the persistence of much that was traditional. Only a small proportion - about ten percent- lived in the cities and towns where education and other resources were concentrated.

Though a few peasant farmers were able at the beginning of the estate boom to plant cash crop rubber this was made increasingly difficult, and most Malays remained resident in village ( $k a-$ 
mpung) society and bound to the largely subsistence economy of padi farming. Part of the ideology of British rule was, indeed, to retain the shape and, so far as possible, style and ethos of the traditional society in the interest of avoiding social unrest. Sultans and sultanate establishments were maintained in style, and the treaties by which the British established their authority explicitly excluded "matters relating to Malay religion and custom".

Islam had taken root in Malaya in the thirteenth to fourteenth centuries and by the late eighteenth and early nineteenth century was a major presence in society, reflected in law and legal institutions, customary practice, public discourse and many aspects of individual and community daily and seasonal life. Qādīs and $n \bar{a}{ }^{\prime} i b$ $q \bar{a} d \bar{\imath} \bar{s}$, usually appointed by the sultanate establishment and sometimes drawn from it, held courts, imāms led prayers in mosques and village suraus, khätibs delivered Friday khutbahs, returned häjjis gave elementary instruction to children in Qur'àn recitation and the elements of the faith, usually in their own homes or the suraus. As in all largely unlettered peasant and similar societies, Islamic praxis often commingled beliefs and practices associated with preIslamic beliefs in the efficacy of magic, thaumaturgy, or alternative ways of coping with the exigencies of life. From time to time, here and there, local rulers or 'ulamä' would institute usually shortlived phases of purification or intensification, urging upon their people a more zealous adherence to shar' 'ah and the observance of ibādah.

It escaped no-one that central to that kind of exercise was education, and it seems probable that the early $19^{\text {th }}$ century offered encouragement or stimulus to Islamic renewal and self-strengthening in a variety of ways. The "Wahhābi $\overline{1}^{\prime}$ or "tauhìd $\bar{l}$ " impulse originating in the Hejaz in the late eighteenth and the first years of the nineteenth century found a powerful presence in West Sumatra from returning häjjis and was certainly known elsewhere. Neo-Süfi tarīgahs (the term originates with Fazlur Rahman) similarly took root at this time in a Malay world that had for long been hospitable to a range of Süfí ideas ${ }^{3}$. The growing British presence in the Straits Settlements of Singapore, Melaka and Penang was accompanied by active Christian proselytising that focused on the provision of schools and the translation into Malay of Christian texts, and could be seen as a threat to Islam.

It is perhaps not surprising, therefore, that the first pondok schools in the peninsula (though the term "school", "sekolah" in 
Malay, did not come into use until much later) seem to date from around this time. The form they took is said to have been introduced from either or both northern Sumatra or the ethnic Malay state of Patani in southern Siam. The latter especially was important, for it was here that the teachings of a notable 'alim, Shaikh Dawud b. Abdullah al-Fatani, flourished in the early years of the nineteenth century and spread into the populous north-eastern Malay state of Kelantan". The word "pondok", from the Arabic "fundüq" (a temporary residence), has the general meaning in Malay of "hut", and was used in this particular context to denote the small, usually one or two-person huts in which students lived while studying with a guru or teacher. Communities of such structures, often very numerous, came to be known collectively as pondoks.

Data about nineteenth century pondoks are scanty, but enough is known to allow some generalisation. Several features are worth remark, relating in particular to their teacher-founders and their own training, their teachings and teaching methods, the murid who attended them, the financing of pondoks, and their relation to state authority. Most if not all pondoks were founded by individual teachers, usually known as To' Guru - - sometimes from the village or district, sometimes incomers, but all themselves the product of traditional learning in the Islamic sciences. This had perhaps been gained in Mecca, but as probably in other pondoks or madrasahs, whether in Patani, Kelantan or elsewhere in the peninsula, from which indeed many had proceeded to Mecca. Standards and breadth of scholarship, and knowledge of Arabic with which to study the texts, were very variable.

A notable To' Guru moving to an area might attract not only local pupils, or murid, but also others from further afield. Several pondoks in Kelantan, for example, the most populous state with a large number of pondoks, attracted murid from Cambodia and Sumatra as well as other peninsula states. Murid usually built their own huts, but were often helped with material and labour by the villagers, for whom the presence of a pondok community was a source of pride as well as an amenity. Huts were simple, oneroom, unpartitioned structures, constructed from bamboo, wood and attap palm thatch, and standing on pillars as did Malay houses. Each was usually occupied by two or perhaps three murid. Larger pondok communities - and some grew to between 250 and 500 murid - might have a central building for teaching purposes, often 
called (somewhat confusingly in view of later usage, but correct etymologically) the madrasah.

The land occupied by or allocated to the pondok community, often several acres in extent, was sometimes owned by the To' Guru, sometimes donated as waqf by one of the better-off farmers. Murid paid no fees, but were provided with food and other consumables by their families, and families and other villagers also made donations to help support the To' Guru, either in the form of "padi zakat" annually or as one-off gifts in kind or money. Some pondok communities grew vegetables and fruit on their own land, and assistant gurus and senior murid might earn a little by teaching recitation of the Qur'ān to children in surrounding villages or by functioning at the range of rituals that punctuated people's personal lives and the calendar year.

The teaching method employed in the pondoks was that of the halaqah, or circle, a system also known in Malay as "buka kitab", opening the book ${ }^{5}$. At the beginning of the session the To' Guru would sit cross-legged on the floor in front of a semi-circle of murid, similarly seated. Opening his copy of whatever text was being learnt, he would start to read, in Arabic but translating it into or expounding it in Malay if necessary, while the murid opened their own books, read with him, and interlined their texts in Malay. The central principles observed were taqlid and hafazan -adherence to past authority and memorization. There was no discussion of the text, no question and answer, for what was being conveyed and recorded mnemonically was a finite body of knowledge not susceptible to inquiry or change ${ }^{6}$.

The subjects taught, from set texts, included Tauhìd, Tafsīr alQur'ān, Hadìth, Ușül al-Figh, Tașazwouf, and Arabic grammar, with a wider range including Mantiq, Balägah, Nahw, Sarf and so forth in the larger and later pondoks. ${ }^{7}$ Murid, whose ages might range anywhere from 9 to 25, were grouped solely according to progress within a given subject, reckoned by completion of memorization of one or another text. Length of residence and study in a pondok might be anything from two to ten years or even longer.

Traditional nineteenth century pondoks, and the countless others of the same pattern established in the years that followed, were of great consequence for Malay rural society, and did much to shape social ethos. The To' Guru, in his person (and after whom the pondok was often named), exemplified Malay (and Muslim) norms of piety and learning, and propriety in behaviour, dress 
(usually in Arab style) and demeanour. Villagers whose daily lives and lack of learning often made it difficult to be "good Muslims" took vicarious reassurance from the presence in their midst of these exemplars. Assistant teachers and senior murid played for parents an important role in ensuring that their children were tutored in the elements of the faith, the fard 'ayn. Pondok communities a variety of dependants, especially elderly men and women (the latter often divorced in a society with a high rate of marital instability), who found there a kind of spiritual old folks home ${ }^{8}$. Graduates of the pondoks, in addition to filling a variety of social roles as qādìs, imams, teachers, and mosque officials and as functionaries of the new religious bureaucracy, formed a significant part of the literate public for the new print media in Malaya - newspapers, journals, books, pamphlets, society organs- produced in increasing profusion from the late nineteenth century.

\section{Twentieth century}

By the end of the nineteenth century, as has been indicated, British rule was well established in the western Malay states and advancing in the rest of the peninsula, together with the institutions that accompanied it. Among these was the piecemeal introduction in rural areas of Malay vernacular schools. Limited to four years of elementary instruction in the 3-Rs, and intended only, as administrators said, to teach their pupils habits of punctuality and make them better farmers and fishermen, their lack of any meaningful economic return rendered them unattractive to many $\mathrm{Ma}-$ lay parents. Others feared that the government schools would take their children away from Islam. But it was clear, nonetheless, that gaining an education was important in the world of the future and the need for this gave further stimulus to the creation of sekolah agama rakyat, independent people's Islamic schools, both pondoks and the new madrasahs.

Government vernacular schools, though they sometimes provided a model for new educational forms ${ }^{9}$, were by no means the sole, or indeed the main force at work. The opening of the Suez Canal in 1869 had led to a significant growth in shipping through the Red Sea, with a correspondingly increased flow both of intending häjjis from Malaya and the Dutch Indies (growing numbers of whom remained in Mecca to study or continued for the same purpose to Cairo), and of Hadramī and other Arabs travelling to Southeast Asia to trade and to teach. At much the same 
time, in the late century and the early years of the new, the teachings of the reformist movement associated with Muhammad 'Abduh, Rashd Ridā and innovations at Al-Azhar, were brought to Malaya by returning häjjis and students, and disseminated by the Cairo journal Al-Manar, which became well known in the peninsula and prompted an influential Malay counterpart, Al-Imam, published in Singapore from early 1906 until the end of 1908.

It was in Al-Imam's columns that an announcement appeared in 1907 heralding the establishment in Singapore of a new, and new kind of madrasah. The Madrasah al-Iqbal al-Islāmiyyah opened in February 1908, backed by the local Arab and Malay reformist founders of Al-Imam and under the patronage of Raja Ali Kelana of Riau. It was headed by a specially engaged Egyptian teacher, Usman Effendi Rafat, who had recruited three additional staff from Cairo. Its formal prospectus noted that it was to be guided by a board of governors, and set out its main features. Subjects taught, in addition to Tajwuīd, 'Tbādah, Akhläq, and Arabic, included Geography and History, Mathematics, English, and Town Planning. The school year of 10 months, beginning annually in the month of Shawwāl, was divided into two four-month semesters, to be followed by a period for revision and examinations.

Initially, the madrasah charged fixed monetary fees, though after criticism these were abandoned. Unsurprisingly, the Madrasah al-Iqbal al-Islāmiyyah has sometimes been described as a secular school with some religious subjects. It is clear, however, that its progenitors saw it as an important step in providing an education that would take account of the need not only for a rejuvenated Islam but for modern secular knowledge as well.

Al-Iqbal al-Islāmiyyah was followed before the first decade of the century was out by at least eight other new-style madrasahs scattered throughout the peninsula — the Madrasah al-Ihsāniyyah in Telok Anson, a rail junction town in Perak; the Madrasah Jam 'iyyah al-Khairiyyah near Muar, Johore; the Madrasah al-Islāmiyyah in Periang; the Madrasah Mașriyyah at Bukit Mertajam, Province Wellesly; the Madrasah Hāmidiyyah in Alor Setar, Kedah; and the Madrasah al-Khairiyyah in Kota Bharu, Kelantan ${ }^{10}$. There is little detailed information about most of these, and when a correspondent of the reformist newspaper Neracha (a successor to Al-Imam under one of the same editors) spoke approvingly in 1913 of the "tens upon tens" of madrasahs now operating in Perak alone ${ }^{11}$, it is not to be supposed that all were as radically novel as Iqbal al-Islāmiyyah. 
Many, indeed, were traditional-style pondoks rebranded to meet changing demand and changing times. Nor did reformist madrasahs necessarily abandon the halaqah and hafazan form of teaching for religious subjects, even where curricula were restructured to admit some secular subjects and some form of exam-based promotion between levels was introduced. Nonetheless, the four decades from 1900 to 1940 on saw the landscape of Islamic education in the peninsula completely transformed in terms of the large numbers of institutions established and the increasingly wide reach of their activities.

A few examples may help to flesh out these generalisations. In Penang, a Qur'ān school dating from 1916, mainly patronised by the local Arab community, transformed itself in 1919 into a madrasah, apparently largely through the interest of the well-known Malay-Arab reformist writer and teacher Sayyid Shaikh b. Ahmad al-Hadi, who after playing a leading role in both Al-Imam and the Madrasah al-Iqbal in Singapore, and latterly opening a Sekolah al-Hadi in Melaka, had moved to Penang. The Madrasah al-Mashhūr al-Islāmiyyah became - appropriately, given its namethe most famous in Malaya, attracting students from all over the peninsula, in part because of the al-Hadi connection and his activities as a publisher, writer and polemicist in the 1920s and early 1930s. Administered by a governing body, with Sayyid Shaikh as Mudìr (director) or Guru Besar (head teacher) for its first three years, the madrasah's senior staff all came from outside Malaya, as did his successor as Mudīr, the Meccan Shaikh 'Abd Allh al-Magrībī. English was taught at the madrasah, but otherwise the curriculum consisted only of the Islamic sciences, with Arabic as the language of instruction. Classes were graded, and promotion was by examination. Many graduates from the school continued their education in the Middle East; from the 1930s 25 a year were assisted by scholarships offered by Saudi Arabia. In 1934, al-Mashhūr started a "sister" madrasah for girls in the house of the mudī", one of the first in Malaya, which later moved to its own premises as the Madrasah al-Mashhūr al-Islāmiyyah, Bahagian Perempuan (Women's Division) $)^{12}$.

In the Parit Jamil area of Johore, originally settled towards the end of the $19^{\text {th }}$ century by immigrant agriculturists from Java, later joined by others from Selangor, Melaka, and Siak in Sumatra, the Madrasah al-Haji Taib was founded in 1921, successor to separate pondok and English schools opened by two brothers, sons of 
the eponymous Haji Taib. The Madrasah had both Arabic and English divisions. The teachers in the Arabic-Islamic division included a Sayyid Abu Bakar Kurud (possibly al-Kurdī), a Shaikh al-Hussain from Egypt, Shaikh Muhammad Amīn from Sudan, and Tengku Mustafa from Aceh. Among visiting teachers was one of the most noted reformist 'ulamā' in Malaya, Shaikh Muhammad Tahir Jalaluddin, whose local influence is said to have extended beyond the murid of the Madrasah to the wider community. ${ }^{13}$

No information is available about the Madrasah's curriculum, but we know that students came to it from other parts of the peninsula. In 1924 the Madrasah formed an association, the Persekutuan Suloh Pelajaran Muar (Torch of Education Society), which published a journal, Masa (Epoch) that circulated widely if rather irregularly in the peninsula for the next decade ${ }^{14}$. Though Madrasah al-Haji Taib, as with all others at this time, taught only male students through the 1920s, like al-Mashhūr it established a special asrama (hostel) for girls in the early 1930s.

The third example is a madrasah that became especially well known after World War II in connection with Malay political nationalism, but whose early years are for that reason also of some interest. The Madrasah Ma'had al-Iyā' al-Sharīf was founded in the district known as Gunong Semanggul, in Kerian, Perak, in 1934. It is worth taking a moment or two to trace its "genealogy", which tells us something about the closely knit world of Islamic education in Malaya at this time. The prime mover in the Madrasah was one Ustaz Abu Bakar al-Bakir b. Muhammad Said, one of six children of a local padi farmer, who had spent five years at a government vernacular school and another five, until 1924, at the traditional Pondok Al-Rahmāniyyah, the eponymous establishment of Haji Abdul Rahman b. Mahmud, who had spent a decade and a half studying at the Haram in Mecca and at Al-Azhar.

On completion of his elementary studies at the Pondok, Abu Bakar moved for six years to the Madrasah Dā'irat al-Ma'ārif in Kepala Batas, to be taught by Ustaz Abdullah Pak Ahim, another Malay graduate from the Haram in Mecca. At the end of this time, under the guidance of Ustaz Abdullah, Abu Bakar and some others started an associated madrasah, the Kanz al-Ma'ārif, where they introduced weekly new-style classes based on question and discussion of texts in the reformist manner. When Ustaz Abdullah was invited by the Sultan of Perak in 1931 to teach at the Madrasah al-Idrisiyyah in the royal capital, Kuala Kangsar, Abu Bakar 
followed him there. Two years later he returned to his birthplace to found al-Ihyâa' al-Sharf in $1934 .{ }^{15}$ It rapidly became known as one of the foremost Kaum Muda (Young Faction, or reformist) madrasahs in Malaya.

It is evident, then, that a great variety of changes were taking place in the realm of formal, but independent, Islamic education in the peninsula during the first four decades of the $20^{\text {th }}$ century. In addition to the sheer number of new institutions, a growing proportion of their teachers was drawn from outside Malaya or from Malays who had completed extensive periods of residence and study in the Hejaz, India (notably at Deoband, but also Aligarh) and increasingly in Cairo. ${ }^{16}$ Many madrasahs were themselves modernising through the introduction of regular terms and graded curricula, substituting nizm (structured) for 'ummūmì (undifferentiated) organisation, and introducing examinations resulting in ijāzah or certificates. The new print culture of the $20^{\text {th }}$ century, along with greatly enhanced communications with the Middle East and the rest of Islamic Southeast Asia, fostered production of newspapers, journals and other publications, some directly associated with madrasahs, that served, especially, the agenda of the Islamic reformists, and also found expression in a host of voluntary associations for self-help, educational, and eventually political purposes in the Islamic interest.

\section{Bureaucratisation of Islamic Authority}

No driver was more important, however, in promoting the expansion of pondok and madrasah education in Malaya in these decades, and in shaping its growth in important respects, than the remarkable process of bureaucratisation of the Islamic authority that took place in the Malay states during the colonial period. As noted earlier, the treaties under which the British assumed authority over the affairs of the separate states excluded "matters relating to Malay religion and custom". What this did, as a consequence of the loss of all Malay specifically political authority, was promote the construction of a wide range of mechanisms relating to Islamic administration and personal Muslim behaviour. Much of this, though often enough taken at the initiative of the sultanate establishment and 'ulamä' (and indeed in protection of their interests), was accomplished through completely new and alien British instruments: state legislative councils expressive of the authority of "the Ruler in Council", and statutory ordinances and enactments. 
By such means, provision was made in each of the states from the 1880s onward - not uniformly, but with considerable similarity - for the registration of "Muhammadan" marriage and divorce; the setting up and regulation of centralised shari 'ah court apparatus; the establishment of Bait al-Māl for control of waqf, intestate properties, the centralized collection of zakāh and management of shari'ah court fines; the proscription of "Muhammadan Offences" (as they were termed, ranging from poor mosque attendance and teaching without an official permit to adultery and fornication); and the creation of state Majlis Agama, "Councils of Religion", whose wide range of powers included the sole right to issue fatwās, license religious teachers, proscribe improper teachings, and appoint all Muslim officials from State Muftīs, Qādīs and assistant Qādìs to village imāms, visiting teachers and extirpators of sin (pencegah ma'siat). Administrative Departments of Religion (Penjabat Agama) were established within the civil service of the states to manage the resulting plethora of Islamic affairs. ${ }^{17}$

These developments generated a swelling demand for growing numbers of Islamically educated personnel to fill posts of every kind and at all levels, supplied for the most part by graduates of the pondok and madrasah schools or by Malays returning from Islamic educational centres in the Middle East.

\section{Post-War}

We must turn now to the processes and events affecting pondoks and madrasahs during the years immediately after the Japanese war and occupation and the return of the British, years characterised by the rise of Malay political nationalism and the struggle for independence. The broader politics of this period, whether of the Malay Left or the centrist United Malays National Organisation (UMNO), are beyond the scope of this essay. 'Ulamä', however - teacher-scholars, officials and others - were involved across the political spectrum, along not easily generalised lines, and two developments in particular merit more detailed mentions.

The radical left Malay National Party (MNP), founded in October 1945, attracted a considerable 'ulamä' following and several prominent 'ulamä' members, including its Vice-President Dr Burhanuddin al-Helmy and the Mudìr of the Madrasah al-Ihya al-Shariff at Gunong Semanggul, Ustaz Abu Bakar al-Bakir. On the initiative of the 'ulama'a' group, a special meeting, held at Gunong Semanggul in March 1946, set up a Supreme Religious Council for 
Malaya (Majlis Agama Tertinggi, MATA), with Ustaz Abu Bakar al-Bakir as president. The Council demanded that the religious powers of the nine separate state rulers be surrendered to a central Islamic authority, a demand that has continued to be expressed, if often less directly, into much more recent times ${ }^{18}$. Unsurprisingly, it was not responded to - the founding president of the centrist UMNO, Dato'Onn b. Jaafar, going so far as to say, oracularly and with manifest reference to Gunong (Mount) Semanggul:

"Before, danger came from the jungle, but mark my words, the danger now is from the mountain"19

At a second MATA conference at Gunong Semanggul a year later, in March 1947, the Council decided to form a political party, the Hisb al-Muslimin, whose aims were the independence of Malaya from colonial rule, building an Islamic society, and creating an Islamic state ${ }^{20}$. Among the bodies set up by Hisb al-Muslimin was a People's Education Authority (Lembaga Pendidikan Rakyat, LEPIR). Employing the slogan "Nationalism and Islam", LEPIR criticised the state religious departments for not providing funding (for example from their centralised zakäh collection) for more "people's schools" and proposed the establishment of a people's university in Malaya, arguing that without education there could be no real freedom. ${ }^{21}$

The career of Hisb al-Muslimin and its agencies was short, for in August 1948, on the outbreak of the Communist insurgency and the British declaration of a state of Emergency, the leadership of the MNP and of its associated Hisb al-Muslimin were imprisoned. Though the party was not banned, it rapidly faded from view. UMNO, however, had recognized that the 'ulamä' were a force to be reckoned with, and in January 1951 Dato' Onn proposed to the party's National Committee that a Persatuan Ulama Malaya ('Ulamä' Union of Malaya) be formed, under UMNO auspices, principally to address issues relating to the unification of Islamic law in the peninsula but with an educational agenda as well. This came into being in August of that year, the members comprising twelve representatives of state religious departments, twelve state muftiss, eighteen UMNO 'ulamä' representatives, and two each non-affiliated Malays, Muslim Indians, and Arabs. ${ }^{22}$ When Onn resigned from UMNO, after a difference with the leadership on other matters, the 'Ulama' 'Union began to dissociate itself from the party 
and from state religious officialdom, becoming in November 1951 the Persatuan Islam-se-Malaya (Islamic Union of Malaya) later the Partai Islam se-Malaya, PAS, today still a leading opposition party. ${ }^{23}$

Throughout these months of tangled negotiations, internal divisions and changing allegiances among the 'ulamä', a common concern existed about education, and in particular what was spoken of -it has the same resonances in English - as sekolah rakyat, people's schools. Early in 1956, following the first federal elections the previous year but still some eighteen months before final independence, the largely Malay administration appointed a special committee to "examine the conditions" of non-government Islamic schools and to make recommendations about any necessary financial assistance.

That the madrasahs and pondoks were in an increasingly parlous position was widely recognised. In addition to the internal problems that the committee went on to highlight, to be outlined in a moment, were several external ones that had been growing for some time. The very success and importance of the independent pondoks and madrasahs had led to increasing state intervention in Islamic education, and the establishment in the 1920s and ' 30 s in all states of "Sekolah Agama Kerajaan" —government religious schools - either by state governments themselves or by their Religious Councils (Majlis Agama) ${ }^{24}$. Integrated to some extent with the state secular system, these set uniform standards for teachers and curricula, and provided examination and certification criteria for employment in the bureaucratic work force, which made them more attractive to aspiring students.

The introduction into the curricula of government vernacular schools of mandatory instruction in the basics of Islam - begun before the war but increased during the decade following it lessened parental need to see their children enter a pondok. And the marked rise in the numbers of Malays returning from university Islamic education in the Middle East —often the products of local madrasahs in the first place- provided an alternative labour pool for bureaucratic employment.

But the most damaging problems were internal. The committee of enquiry's report expressed "sadness" at the "much neglect$\mathrm{ed}^{\prime \prime}$ state of non-government Islamic schools ${ }^{25}$. Following visits to 76 pondoks and madrasahs, large and small, throughout the peninsula over a period of more than two months, the committee noted a 
daunting range of shortcomings ${ }^{26}$. Administration and management were poor and often reliant solely on the founder and his assistants, with no board of trustees or governing body. The financial position of most institutions was precarious - dependent on an uncertain combination of very small fees from poor parents, donations, waqf properties, and in some cases small subventions from state religious departments. Teachers' salaries were "grossly inadequate", teaching standards very variable, and teaching methods often unsatisfactory. The absence of any "uniformity of syllabus" or of reliable certification systems made transferring between them or into other educational establishments difficult. There was little attempt in most to teach anything other than religious subjects. ${ }^{27}$

The report made a number of recommendations, in particular that differential, though uniformly small, amounts of financial aid be given by state religious departments to all schools, subject to compliance with conditions relating to systems of governance, curricular level, upgrading of teachers and of teaching standards and similar matters, with the grants to be administered by the federal Ministry of Education. Few if any of the recommendations seem to have been carried out in the short term, though some of the states did take over or assist a few of the schools.

It was not until 1972, as the predominantly youthful da 'wah (Islamic intensification) movement gathered strength, that the Malaysian Ministry of Education set up a special division to improve the administration of all aspects of Islamic education, directed especially at independent or grant-aided schools ${ }^{28}$. Institutions assisted in some measure by federal or state funding remained numerous and continued to send some graduates to the Middle East or to the tertiary Kolej Islam Malaya (established in 1955) ${ }^{29}$ for higher education, but they continued for the most part to be structurally weak and curricularly limited. ${ }^{30}$

As the independent madrasahs and their role in producing ' $u$ lam $\vec{a}$ ' declined in the late 1960s and after, the federal government responded to political and social pressures for the "Islamization" of public services by introducing a wide range of measures affecting economic, judicial and other institutions. Where education was concerned these provided for a larger quantum of compulsory teaching of Islamic knowledge to Malays in all state schools through the eleven years of primary and secondary education, founding an Islamic teachers' training college, introducing measures to im- 
prove text-books from an Islamic point of view, and signing up to the "Islamization of knowledge" agenda set out as a result of the first World conference on Muslim education in Mecca in 1977 and its successors. ${ }^{31}$

But there was little place in all this for the old independent pondoks and madrasahs, and it seems inevitable that they will continue to decline, giving way increasingly to establishments funded in whole or part by the state, and teaching according to criteria established by the relevant section of the Ministry of Education and other state arbiters of proper Islamic thought and practice. 


\section{Endnotes}

1. An earlier version of this essay was presented at the Autumn 2003 seminar of the Oxford Centre for Islamic Studies, and I am grateful for helpful comments and discussion on that occasion.

2. See, e.g., Zamaksyari Dhofier, Tradisi Pesantren: Studi tentang Pandangan Hidup Kyai (Jakarta: LP3ES, 1982); Dawam Rahardjo (ed.), Pesantren dan Pembaharuan (Jakarta: LP3ES, 1985 [1st publ. 1974]; idem, Pergulatan Dunia Pesantren: Membangun dari Bawah (Jakarta: Perhimpunan Pengembangan Pesantren dan Masyarakat, 1985). Cf. also Clifford Geertz, "The Javanese Kijaji: the Changing Role of a Cultural Broker", Comparative Studies in Society \& History, 2 (1959-60), pp. 228-249.

3. One of the principal tarigahsto enter Malaya around this time was the Ahmādiyyah-Idrīsiyyah (see Mark J.R. Sedgwick, The Heirs of Ahmad Ibn Idris: the Spread and Normalization of a Sufi Order, 1799-1996 (Bergen, University of Bergen, 1998)).

4. On Shaikh Daud, see, e.g., Mohd. Zain Abdul Rahman, "New lights on the life and works of Shaikh Dawud al-Fatani", Studia Islamika, 9:3 (2002), pp. 83-117, and Virginia Matheson \& M.B. Hooker, "Jawi literature in Patani: the Maintenance of an Islamic Tradition", Journal of the Malayan Branch Royal Asiatic Society, 61:1 (1988), pp.14 \& 19-26.

5. Also known as "tadah kitab", which might be translated as "accepting the book".

6. On this, see.Dale F. Eickelman, "The Art of Memory: Islamic Education and its Social Reproduction", in Juan R.I.Cole (ed.), Comparing Muslim Societies: Knowledge and the State in World Civilization (Ann Arbor, MI: University of Michigan Press, 1992, pp.97-132. (Rev. version of article orig. publ. in Comparative Studies in Society \& History, 20 (1978). Though from the point of view of the murid the text was unalterable and not open to question, many such texts were in fact adaptations from Arabic or other originals.

7. For a brief discussion of texts used in Malaya, see Mohd. Nor b. Ngah, Kitab Jawi: Islamic Thought of the Malay Muslim Scholars (Singapore: Institute of Southeast Asian Studies, 1982). Virginia Matheson \& B.M. Hooker, "Jawi Literature in Patani", op. cit., pp. 1-86, provides an important description of texts published in southern Thailand at this time that also circulated widely in Malaya. Martin van Bruinessen, "Kitab Kuning: Books in Arabic Script Used in the Pesantren Milieu", Bijdragen tot de Taal-, Land-en Vlkenkunde, 146 (1990), pp.226-269, though dealing with Indonesia, also includes material familiar in the peninsula.

8. On the last, see Robert L. Winzeler, "Traditional Islamic Schools in Kelantan", Journal, Malaysian Branch Royal Asiatic Society, XLV (1975)

9. See, e.g., Mohd Jani Naim, "Sekolah Agama Rakyat di Sabak Bernam hingga 1945", in Islam di Malaysia, ed.Khoo Kay Kim \& Mohd Fadzil Othman (Kuala Lumpur: Penerbitan Persatuan Sejarah Malaysia, n.d [1979]) p.55;

10. Sources differ on founding dates but all were within the decade. See, e.g., Ibrahim b. Abu Bakar, Islamic Modernism in Malaya:The Life and Thought of Sayid Syeikh Al-Hadi 1867-1934 (Kuala Lumpur: University of Malaya Press, 1994) p. 105.

11. Neracha, August 20, 1913.

12. A short history of Madrasah al-Mashhur is given in Rahim b.Osman, "Madrasah Masyhur al-Islamiyyah, Pulau Pinang", in Islam di Malaysia, op.cit., 
pp.75-85. The al-Mashhur name was apparently that of an elderly and muchrespected Penang sayyid (ibid., p.77). Cf. also Ibrahim b. Abu Bakar, op. cit., which provides a biography of Sayyid Shaikh as well as some discussion of the early years of the Madrasah.

13. Shaikh Tahir was born in West Sumatra in 1869. Educated there, then with distinguished teachers in Mecca, and finally at Al-Azhar, he returned to Southeast Asia in 1899, living and working thereafter primarily in Malaya.

14. On the history of the Madrasah, see Saman b. Sariff, "Madrasah al-Haji Taib, Kampung Parit Jamil, Muar", in Islam di Malaysia, op.cit., pp.86-97; on Masa, see William R. Roff, Bibliography of Malay and Arabic Periodicals published in the Straits Settlements and Peninsular Malay States 1876-1941 (London: Oxford University Press), pp.36-37.

15. Nabir b. Haji Abdullah, Maahad Il Ihya Assyariff Gunung Semanggol 1934-59 (Bangi: Jabatan Sejarah Universiti Kebangsaan Malaysia, 1976) gives a detailed description of the early history of the madrasah, based in part on an unpublished written account by Abu Bakar.

16. On Malay students in Cairo at this time, see William R. Roff, "Malay and Indonesian Students in Cairo in the 1920s", Indonesia (Ithaca), 9 (April1970), pp.73-88.

17. This complex process, so summarily outlined here, has yet to find an extended historical account. The following supply some data: William R.Roff, The Origins of Malay Nationalism (New Haven. CT: Yale University Press, 1967), pp.72-74; idem, "Patterns of Islamization in Malaysia, 1890s - 1990s: exemplars, Institutions, and vectors", Journal of Islamic Studies, 9:2 (1998), pp.211-212. Cf. also Thomas F. Willer, Religious Administrative Development in Colonial Malay States, 1870-1941 (Unpublished PhD dissertation, University of Michigan, 1975).

18. On similar appeals in the late 1940 s and early 1950 s made by the prominent madrasah 'älim Fadlullah Suhaimi, Dato'Onn and others, see Safie b. Ibrahim, The Islamic Party of Malaysia: Its Formative Stages and Ideology (Pasir Puteh,Kelantan: Nawawi b. Ismail, 1982), pp.16-19.

19. Utusan Melayu, 11 June 1946, cited in Ramlah Adam, Dato' Onn Ja'afar: Pengasas Kemerdekaan (Kuala Lumpur: Dewan Bahasa \& Pustaka, 1992), p.174, n.14.

20. Ibid., p.174. See also the lengthy account in Nabir, op.cit., pp.159ff.

21. Nabir, op.cit., pp.177-180

22. Ramlah, op.cit., p.175, n.16

23. Safie, op.cit., pp. $25 \mathrm{ff}$

24. This was a process that, like several others relating to pondoks and madrasahs, began in Kelantan.

25. Report of the Committee to Consider Financial Aids to Non-Government Islamic Religious Schools (Kuala Lumpur: Government Printer, 1957), p.3.

26. Appendix ' $B$ ' to the report (pp.15-48) lists by name and state 401 nongovernment religious schools with 35,093 students and1,174 teachers though certain aspects of the figures are unclear.

27. Ibid., pp.3-5. For a discussion of these issues, see Hj. Abdullah Ishak, Pendidikan Islam dan Pengaruhnya di Malaysia (Kuala Lumpur: Dewan Bahasa \& Pustaka, 1995), pp. $237 \mathrm{ff}$.

28. Though numbers had fallen, there were still some 16,500 students studying at independent sekolah agama rakyat in the late 1980s (compared with 35,000 
at the time of the 1955 report), with three times that number at either federal or state grant-aided religious schools (see Mohd. Kamal Hassan et al, "Konsep pendidikan Islam dan matlamat persekolahan agama dan Arab di Malaysia", in Ismail b. Rahman (ed), Pendidikan Islam Malaysia: Bangi, Penerbit Universiti Kebangasaan Malaysia, 1992), p.49.

29. For a brief historical account of the Kolej Islam, see Muslim College Malaya: Origin and Developments 1955-1958 (Kelang: Muslim College Malaya, n.d.[1958], pp.2-4.

30. Mohd. Kamal Hassan et al., in "Konsep pendidikan Islam", op cit., p.52

31. Though there is a varied general literature on this subject, little refers directly to Malaysia. See, however, Mona Abaza, Debates on Islant and Knowledge in Malaysia and Egypt (London: RoutledgeCurzon, 2002).

William R. Roff, Emeritus Professor of History, Columbia University, New York, and Honorary Fellow Department of Islamic and Middle East Studies, University of Edinburgh. 